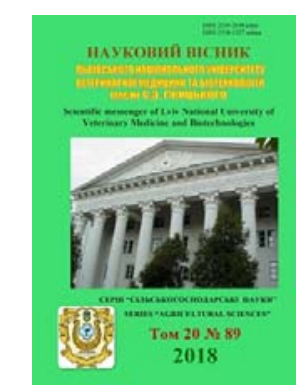

Науковий вісник Дьвівського національного університету ветеринарної медицини та біотехнологій імені С.3. Гжицького

\author{
Scientific Messenger of Lviv National University \\ of Veterinary Medicine and Biotechnologies
}

UDC:577.1:612.015

\title{
Indicators of functional and antioxidant liver status of rats under oxidative stress conditions and on the action of the liposomal drug "Butaselmevit"
}

\author{
T.V. Martyshuk ${ }^{1}$, B.V. Gutyj ${ }^{2}$, O.I. Vishchur ${ }^{1}$ \\ ${ }^{1}$ Institute of animal biology NAAS, Lviv, Ukraine \\ ${ }^{2}$ Stepan Gzhytskyi National University of Veterinary Medicine and Biotechnologies Lviv, Ukraine
}

Article info

Received 19.09.2018

Received in revised form 22.10.2018

Accepted 23.10.2018

Institute of Animal Biology of NAAS, V. Stusa Str., 38, Lviv, 79000, Ukraine.

Stepan Gzhytskyi National University of Veterinary Medicine and Biotechnologies Lviv,

Pekarska Str., 50, Lviv, 79010, Ukraine.

Tel.: +38-068-136-20-54 E-mail:bvh@ukr.net

\begin{abstract}
Martyshuk, T.V., Gutyj, B.V., \& Vishchur, O.I. (2018). Indicators of functional and antioxidant liver status of rats under oxidative stress conditions and on the action of the liposomal drug “Butaselmevit”. Scientific Messenger of Lviv National University of Veterinary Medicine and Biotechnologies, 20(89), 100-107. doi: 10.32718/nvlvet8919
\end{abstract}

The purpose of the work was to study the parameters of the functional and antioxidant state of the liver in rats under conditions of oxidative stress and at the actions of the liposomal drug "Butaselmevit". The research was carried out on young white laboratory male rats of the Vistar line with a body weight of 180-200 g, which were kept in the standard conditions of the institute vivarium of the State Scientific Research Control Institute of Veterinary Preparations and Feed Additives. Animals were divided into three groups of 20 animals in each: 1st group (K) intact animals; 2nd group (D1) - rats, affected with tetrachloromethane; group 3 (D2) - rats, affected with tetrachloromethane and treated with Botselmevit liposomal preparation. Toxic lesion of rats was caused by intramuscular administration of 50\% tetrachloromethane at a dose of $0.25 \mathrm{ml}$ per $100 \mathrm{~g}$ of animal body weight for the first and third day of the study. Animals of the experimental group D2 on the first and third day of the study, an hour after the introduction of tetrachloroethane, additionally administered a liposomal preparation at a dose of $2 \mathrm{ml}$ per $1 \mathrm{~kg}$ of body weight of the animal. The composition of this preparation includes the following substances: butafosfan, selenium, methionine, thistle injection and vitamins A, E and D3. The development of oxidative stress in rats caused by intramuscular administration of tetrachloromethane was accompanied by suppression of protein synthesis of the liver, as evidenced by the low level of total protein and the decrease in the albumin-globulin factor. Low levels of albumin and high levels of globulins in the blood of diseased rats indicate an albumin-globulin disproportion. The indicators of liver function were quite high, namely: the level of creatinine increased by $46 \%$, urea by $74 \%$ and total bilirubin by $34 \%$. When applying the liposomal drug "Butaselmevit" to rats, under conditions of oxidative stress during research, the normalization of biochemical parameters occurs in the blood. It has been proven that modeling of the stress response in rats of the experimental group leads to a probable decrease in the level of reduced glutathione and the activity of glutathione peroxidase in the second and fifth days of the experiment. When applying the liposomal drug Butaselmevit to rats, under conditions of oxidative stress during the studies, activation of the glutathione linkage of the antioxidant system occurs in the blood, indicating an increase in the level of reduced glutathione and the activity of glutathione peroxidase in the blood of animal data. At the 14th day of the research, the level of reduced glutathione and the activity of glutathione peroxidase in blood of the experimental group D2 were the highest. The results of the research indicate the antioxidant properties of the new liposomal drug "Butaselmevit".

Key words: oxidative stress, liposomal preparation “Butaselmevit”, blood, vitamins, selenium, butaphosphon, methionine, thistle spotty.

\section{Показники функціонального та антиоксидантного стану печінки щурів за умов оксидаційного стресу та за дії ліпосомального препарату "Бутаселмевіт"}

\author{
Т.В. Мартишук ${ }^{1}$, Б.В. Гутий², О.І. Віщур ${ }^{1}$ \\ ${ }^{1}$ Інститут біології тварин НААН, м. Львів, Україна \\ ${ }^{2}$ Львівський національний університет ветеринарної медицини та біотехнологій імені С.3. Гљсицького,
}


Метою роботи було вивчити показники функціонального та антиоксидантного стану печінки цурів за умов оксидаційного стресу та за дії ліпосомального препарату “Бутаселмевіт”. Дослідження проводили на молодих білих лабораторних иурахсамиях лінї Вістар масою тіла 180-200 г, які утримувалися у стандартних умовах інститутського віварію Державного науководослідного контрольного інституту ветеринарних препаратів та кормових добавок. Тварин було поділено на три групи по 20 тварин у кожній: 1-ша група (К) інтактні тварини; 2-га група (Д 1 - шурі, ураженні тетрахлорметаном; 3-тя група (Д2) - иурі, ураженні тетрахлорметаном та ліковані ліпосомальним препаратом “Бутаселмевіт”. Токсичне ураження шурів викликали шляхом внутрішньом'язової ін'єкції 50\% тетрахлорметану у дозі 0,25 мл на 100 г маси тіла тварини на першу і третю добу досліджень. Тваринам дослідної групи Д2 на периу і третю доби досліджень за годину після введення тетрахлоретану додатково вводили ліпосомальний препарат у дозі 2 мл на 1 кг маси тіла тварини. У склад даного препарату входять наступні речовини: бутафосфан, селен, метіонін, розторопша ін'єкиійна та вітаміни А, Е і Дз. Розвиток оксидачійного стресу у иурів, викликаний внутрішньом'язовим введенням тетрахлорметану, супроводжувався пригніченням протеїнсинтезувальної функиії печінки, на щзо вказує низький рівень загального протеїну та зниження альбуміно-глобулінового коефіцієнту. Низький рівень альбумінів та високий рівень глобулінів у крові хворих щурів вказує на альбуміно-глобулінову диспропориію. Досить високими були показники функціонального стану печінки, а саме: рівень креатиніну зріс на 46\%, сечовини на 74\% та білірубіну загального на $34 \%$. Після застосування ліпосомального препарату “Бутаселмевіт” иурам, за умов оксидаційного стресу протягом досліджень, у крові наступила нормалізація біохімічних показників. Встановлено, щео моделювання стресової реакиії у шурів дослідної групи призводить до вірогідного зниження рівня відновленого глутатіону та активності глутатіонпероксидази на другу та п'яту доби експерименту. Після застосування ліпосомального препарату “Бутаселмевіт” шурам, за умов оксидаційного стресу протягом досліджень, у крові наступає активізація глутатіонової ланки антиоксидантної системи, на щзо вказує збільшення рівня відновленого глутатіону та активності глутатіонпероксидази у крові даних тварин. На 14 добу досліду рівень відновленого глутатіону та активність глутатіонпероксидази у крові дослідної групи Д2 були найвищими. Проведені результати досліджень вказують про антиоксидантні властивості нового ліпосомального препарату “Бутаселмевіт”.

Ключові слова: оксидаційний стрес, ліпосомальний препарат “Бутаселмевіт”, кров, вітаміни, селен, бутафосфан, метіонін, рослинна сировина.

\section{Вступ}

Хімічні сполуки відносяться до постійно діючих на організм тварин факторів навколишнього середовища. Між зовнішнім хімічним оточенням і хімічним складом організму існує певна рівновага, порушення якої приводить до зрушення гомеостазу. В останні десятиріччя у світі формується токсична ситуація, яка обумовлена інтенсивним впровадженням хімічних речовин у промисловість, сільське господарство, гуманну і ветеринарну медицину та зростанням числа гострих та хронічних отруєнь (Li et al., 2012; Gutiy, 2012; Gutyj, 2016). Відомо, що центральними органом, який забезпечує процеси дезінтоксикації організму є печінка (Calabrese et al., 1996; Cherkashina and Petrenko, 2006; Hariv and Gutyj, 2016). Вона відіграє визначну роль у проміжному обміні амінокислот та вуглеводів, синтезі і розпаді білків і глікопротеїнів, регулюванні обміну жирів та холестерину, метаболізмі і руйнуванні гормонів, лікарських речовин та ксенобіотиків. Серед дифузних уражень печінки велика увага приділяється токсичним ураженням печінки (Sato et al., 1999; Batakov, 2001; Yatsenko and Maloshtan, 2004). Останніми роками встановлено роль у патогенезі захворювань печінки процесів активації вільнорадикального окиснення ліпідів плазматичних і внутрішньоклітинних мембран гепатоцитів на тлі виснаження захисних протирадикальних систем (Abragamovich et al., 2000; Hariv and Gutyj, 2016). I3 літературних джерел відомо, що надлишкове накопичення продуктів перекисного окиснення ліпідів викликає набряк мітохондрій, роз'єднання процесів дихання та окисного фосфорилювання, ушкодження сульфгідрильних груп тіолових ензимів (Gutyj et al., 2016; Khariv et al., 2016). Фактори, що викликають оксидативний стрес - порушення окисно-відновної рівноваги в бік окиснення і утворення вторинних вільних радикалів. До патологічних порушень гомеостазу, які призводять до оксидаційного стресу, зокрема, відносять: зміна гомеостазу у результаті дії патологічних чинників; зміна гомеостазу у результаті порушення генетичної інформації; дефект регулюючої системи або органу-мішені (Martyshuk et al., 2016; Huberuk et al., 2017). За дії патологічного чинника проходить зміна інтенсивності перекисного окиснення ліпідів, накопичення в крові концентрації продуктів вільнорадикального окиснення та активних форм кисню, зниження буферної ємності крові відносно підтримування оптимальних параметрів інтенсивності вільнорадикальних реакцій (Lavryshyn et al., 2016; Khariv et al., 2017).

Розробка методів інтегральної корекції оксидаційного стану в організмі тварин за дії різних чинників ризику є важливим фактором у процесі створення біобезпечних та високоефективних препаратів парентерального та перорального призначення. Для підвищення адаптаційної здатності й імунобіологічної реактивності організму, посилення протеїнсинтезувальної та ензимної функції у тварин в останні роки 3 успіхом використовують нові комплексні препарати (Lee et al., 2004; Skry'pny'k, 2007; Saba et al., 2010). Окремими авторами встановлено стимулювальний вплив розторопші плямистої, вітамінів, Селену та бутафосфану на активність антиоксидантної та гепатопротекторної дії у тварин (Antonyak et al., 2000; Belenichev et al., 2002). Однак комплексне застосування вказаних препаратів на функцію печінки та гематологічні показники на даний час у науковій літературі висвітлене недостатньо.

Саме тому, метою нашої роботи було вивчити показники функціонального та антиоксидантного стану печінки щурів за умов оксидаційного стресу та за дії ліпосомального препарату “Бутаселмевіт”. 


\section{Матеріал і методи досліджень}

Дослідження проводили на молодих білих лабораторних щурах-самцях лінії Вістар масою тіла 180 200 г, які утримувалися у стандартних умовах інститутського віварію Державного науково-дослідного контрольного інституту ветеринарних препаратів та кормових добавок. Упродовж усього експерименту щурів утримували на збалансованому раціоні, що містив усі необхідні компоненти, питну воду тварини отримували без обмежень із скляних поїлок об'ємом 0,2 літра.

Тварин було поділено на три групи по 20 тварин у кожній: 1-ша група (К) інтактні тварини; 2-га група (Д) - щурі, ураженні тетрахлорметаном; 3-тя група (Д2) - щурі, ураженні тетрахлорметаном та ліковані ліпосомальним препаратом "Бутаселмевіт". Токсичне ураження щурів викликали шляхом внутрішньом'язевої ін'єкції 50\% тетрахлорметану у дозі 0,25 мл на 100 г маси тіла тварини на першу і третю добу досліджень. Тваринам дослідної групи Д2 на першу і третю доби досліджень за годину після введення тетрахлоретану додатково вводили ліпосомальний препарат у дозі 2 мл на 1 кг маси тіла тварини. В склад даного препарату входять наступні речовини: бутафосфан, Селен, метіонін, розторопша ін'єкційна та вітаміни А, Е і Д .

Кров для біохімічних досліджень забирали під ефірним наркозом 3 яремної вени на другу, п’яту, десяту та п’ятнадцяту доби експерименту.

У сироватці крові досліджували: рівень загального протеїну біуретовою пробою, а вміст окремих його фракцій - турбідиметричним методом за Л.М. Делекторською (1971); концентрацію загального білірубіну - за методом Сндрашика і Грофа в модифікації В.І. Левченка і В.В. Влізла (1988); концентрацію сечовини - за кольоровою реакцією 3 діацетилмонооксимом (Петрунь Н.М. і співавт., 1970); вміст креатиніну за методом Яффе-Поппера (1972). Глутатіонпероксидазну активність (ГП) визначали за швидкістю окиснення глутатіону в присутності гідроперекису третинного бутилу та вміст відновленого глутатіону в еритроцитах крові (Vlizlo et al., 2012).

Утримання, годівлю, догляд т а усі маніпуляції з тваринами здійснювали згідно з Європейською конвенцією "Про захист хребетних тварин, які використовуються для експериментальних і наукових цілей” (Страсбург, 1986 р.) і “Загальних етичних принципів експериментів на тваринах", ухвалених Першим Національним конгресом $з$ біоетики (Київ, 2001). Експерименти проводили 3 дотриманням принципів гуманності, викладених у директиві Свропейської Спільноти.

\section{Результати та їх обговорення}

Протеїн вважається головним елементом, за рахунок якого відбувається внутрішній процес “будівництва” в організмі. Він підтримує плинність крові, іiі в'язкість та визначає необхідний в судинному руслі об'єм крові. За рахунок протеїнів формені елементи утримуються в підвішеному стані, а також, здійснюється транспортування найважливіших екзогенних та ендогенних речовин. Завдяки протеїнам регулюється рівень $\mathrm{pH}$ середовища в крові. Активну участь протеїн бере і в реакціях імунного характеру.

Велика частина протеїну синтезується безпосередньо у печінці. Гепатоцити синтезують альбумін і фібриноген, альфа і бета-глобуліни, а також, компоненти системи згортання крові. Найбільша частина бетаглобулінів синтезується прямо в клітинахлімфоцитах.

Про стан протеїнсинтезувальної функції печінки вказує рівень загального протеїну, а саме його альбумінової фракції, у сироватці крові тварин за різних патологічних станів організму. Адже $80 \%$ альбумінів синтезується гепатоцитами у печінці

У наших дослідах (табл. 1) встановлено, що за умов оксидаційного стресу у щурів дослідної групи Д 1 рівень загального протеїну вірогідно знижується на 2-у добу досліду, де відповідно він становив 58,8 \pm 1,75 г/л, тоді як у контрольній групі тварин він був у межах величин 65,3 \pm 1,80 г/л. На 5, 10 і 14-ту доби досліду рівень досліджуваного показника дещо зріс, однак порівняно 3 контрольною групою тварин залишався низьким. Зниження загального протеїну відбувалося за рахунок зменшення альбумінової фракції. Так, на 2-у добу досліду рівень альбумінів у крові щурів дослідної групи Д 1 знизився на 41\%, а на 5-ту добу - на 44\% відносно показників тварин контрольної групи.

Поряд із зниженням альбумінів у сироватці крові хворих щурів виявляли незначне підвищення глобулінової фракції, так на 2 і 5-ту доби досліду, рівень глобулінів відповідно зріс на 7 і 6\%. У подальшому рівень глобулінів залишався у тих самих межах величин, як і на 5 добу досліду.

Дані дослідження вказують на альбуміноглобулінову диспропорцію у сироватці крові хворих щурів. Внаслідок цього величина $\mathrm{A} / \Gamma$ коефіцієнта на 2-у добу досліду становила 0,29 \pm 0,02 проти $0,53 \pm$ 0,02 у контрольної групи корів. Така величина коефіцієнта вказує на пригнічення протеїнсинтезувальної функції печінки корів.

Після застосування ліпосомального препарату “Бутаселмевіт" щурам дослідної групи Д2, за інтоксикації тетрахлорметаном нами встановлено підвищення рівня загального протеїну та альбумінової фракції, а також зниження рівня глобулінів у сироватці крові щурів 2 і 5-ту доби досліджень. На 10 і 14-ту доби досліджень у щурів другої дослідної групи виявили нормалізацію показників протеїнсинтезувальної функції печінки. У межах фізіологічних величин був і також $\mathrm{A} / \Gamma$ коефіцієнт.

Функціональний стан печінки щурів, інтоксикованих тетрахлорметаном, визначали за рівнем у сироватці крові сечовини, білірубіну та креатиніну (табл. 1). 


\section{Таблищя 1}

Показники функціонального стану печінки щурів за умов оксидаційного стресу та за дії ліпосомального препарату $(\mathrm{M} \pm \mathrm{m} ; \mathrm{n}=20)$

\begin{tabular}{|c|c|c|c|c|c|}
\hline \multirow{2}{*}{ Показник } & \multirow{2}{*}{$\begin{array}{c}\text { Дослідна } \\
\text { група } \\
\end{array}$} & \multicolumn{4}{|c|}{ Доба досліджень } \\
\hline & & Друга & П'ята & Десята & Чотирнадцята \\
\hline \multirow{3}{*}{$\begin{array}{l}\text { Протеїн загальний, } \\
\text { г/л }\end{array}$} & $\mathrm{K}$ & \multicolumn{4}{|c|}{$65,3 \pm 1,80$} \\
\hline & $Д_{1}$ & $59,1 \pm 1,33^{*}$ & $57,9 \pm 2,05^{*}$ & $60,2 \pm 1,95$ & $62,4 \pm 2,10$ \\
\hline & Д$_{2}$ & $58,8 \pm 1,75$ & $62,9 \pm 1,08$ & $64,6 \pm 0,87$ & $66,4 \pm 1,23$ \\
\hline \multirow{3}{*}{ Альбуміни, г/л } & K & \multicolumn{4}{|c|}{$22,6 \pm 1,25$} \\
\hline & $Д_{1}$ & $13,3 \pm 1,60 * *$ & $12,7 \pm 2,22 * *$ & $14,9 \pm 1,90^{*}$ & $17,6 \pm 1,85$ \\
\hline & Д2 & $14,1 \pm 1,92 * *$ & $18,9 \pm 1,35$ & $21,1 \pm 1,55$ & $22,7 \pm 0,83$ \\
\hline \multirow{3}{*}{$\begin{array}{l}\text { Глобуліни, } \\
\text { г/л }\end{array}$} & K & \multicolumn{4}{|c|}{$42,7 \pm 1,41$} \\
\hline & Д$_{1}$ & $45,8 \pm 2,23$ & $45,2 \pm 2,63$ & $45,3 \pm 1,75$ & $44,8 \pm 2,23$ \\
\hline & $Д_{2}$ & $44,7 \pm 1,82$ & $44,0 \pm 2,20$ & $43,5 \pm 1,60$ & $43,7 \pm 1,70$ \\
\hline \multirow{3}{*}{ Коефіціент, А/Г } & K & \multicolumn{4}{|c|}{$0,53 \pm 0,02$} \\
\hline & $Д_{1}$ & $0,29 \pm 0,02 * * *$ & $0,28 \pm 0,03^{* * *}$ & $0,33 \pm 0,04 * *$ & $0,39 \pm 0,03^{*}$ \\
\hline & Д$_{2}$ & $0,32 \pm 0,02 * * *$ & $0,43 \pm 0,04$ & $0,49 \pm 0,02$ & $0,52 \pm 0,03$ \\
\hline \multirow{3}{*}{$\begin{array}{l}\text { Креатинін, } \\
\text { мкмоль/л }\end{array}$} & K & \multicolumn{4}{|c|}{$66,3 \pm 2,56$} \\
\hline & $Д_{1}$ & $96,5 \pm 3,22 * * *$ & $95,2 \pm 4,35 * *$ & $88,5 \pm 3,37 * *$ & $81,7 \pm 3,50^{*}$ \\
\hline & Д $_{2}$ & $94,9 \pm 3,75^{* * *}$ & $84,9 \pm 3,76^{* *}$ & $72,8 \pm 2,84$ & $68,9 \pm 3,87$ \\
\hline \multirow{3}{*}{$\begin{array}{l}\text { Сечовина, } \\
\text { мкмоль/л }\end{array}$} & $\mathrm{K}$ & \multicolumn{4}{|c|}{$6,6 \pm 0,91$} \\
\hline & $Д_{1}$ & $11,5 \pm 1,71^{*}$ & $10,9 \pm 1,23^{*}$ & $10,0 \pm 1,14$ & $9,2 \pm 0,58$ \\
\hline & Д$_{2}$ & $11,1 \pm 1,37^{*}$ & $9,0 \pm 0,75$ & $7,8 \pm 0,63$ & $6,5 \pm 0,90$ \\
\hline \multirow{3}{*}{$\begin{array}{l}\text { Білірубін } \\
\text { загальний, мкмоль/л }\end{array}$} & K & \multicolumn{4}{|c|}{$3,89 \pm 0,57$} \\
\hline & $Д_{1}$ & $5,21 \pm 0,73$ & $5,02 \pm 0,66$ & $4,57 \pm 0,93$ & $4,46 \pm 0,65$ \\
\hline & $Д_{2}$ & $4,82 \pm 0,65$ & $4,39 \pm 0,85$ & $4,08 \pm 0,51$ & $3,92 \pm 0,71$ \\
\hline
\end{tabular}

Ступінь вірогідності:* - $\mathrm{P}<0,05 ; * *-\mathrm{P}<0,025 ; * * *-\mathrm{P}<0,001$

Важливим показником функціонального стану печінки є рівень сечовини у сироватці крові, оскільки ії синтез відбувається на припортальних гепатоцитах. Печінка $є$ органом, в якому знешкоджується основна кількість аміаку. До 85\% аміаку, що утворюється в кишечнику тварин, в печінці трансформується в сечовину. I чим більша кількість аміаку надходить до печінки, тим більше утворюється сечовини, на що вказує їі рівень у сироватці крові.

Встановлено, що на 2-у добу досліду у щурів дослідної групи Д рівень сечовини у сироватці крові становив 11,5 \pm 1,71 мкмоль/л. На 5-ту добу цей показник знизився до 10,9 $\pm 1,23$ мкмоль/л. На 10-у добу рівень сечовини у сироватці крові хворих щурів знизився до $10,0 \pm 1,14$ мкмоль/л, що на 52\% вищий від показників щурів контрольної групи. На такому ж рівні вміст сечовини у сироватці крові хворих щурів утримувався і на 14 добу.

Після дослідження впливу ліпосомального препарату "Бутаселмевіт" на організм щурів, за умов отруєння тетрахлорметану, встановлено, що у сироватці крові щурів дослідної групи Д2 рівень сечовини на 2-у добу досліду коливався у межах величин $11,1 \pm$ 1,37 мкмоль/л. На 5 і 10-ту доби досліду рівень сечовини у сироватці крові дослідних щурів поступово знижувався, однак відносно контрольної групи тварин він був вищим на 36 і 18\%. На 14-ту добу досліду рівень сечовини доходив до меж фізіологічних величин.

Важлива фармакологічна функція печінки полягає в участі іï у пігментному обміні за метаболічних процесів. Функцію печінки визначають за рівнем загального білірубіну в сироватці крові. За умови розладів пігментної функції печінки зменшується поглинання, кон'югація та екскреція білірубіну в жовч, що призводить до підвищення його рівня у сироватці крові.

У наших дослідах встановлено, що у щурів, за умов отруєння тетрахлорметаном, рівень загального білірубіну в сироватці крові на 2-у добу підвищився на $34 \%$, а на 5-ту добу - на 29\% відносно контролю. На такому високому рівні вміст загального білірубіну у сироватці крові щурів дослідної групи Д1, був на 10 і 14-ту доби досліджень.

Креатинін є кінцевим продуктом азотового обміну. Він утворюється в м'язовій тканині із фосфокреатину. Рівень креатиніну в сироватці крові $\epsilon$ індикатором стану видільної функції нирок. У щурів дослідної групи Д1, вміст креатиніну в сироватці крові з 2 по 14ту добу досліду коливався у межах величин 96,581,7 мкмоль/л.

За дії ліпосомального препарату у щурів другої дослідної групи, яким вводили тетрахлорметан нами встановлено нормалізацію показників рівня креатиніну та білірубіну загального на 5-ту і 10-ту доби досліджень. На 14-ту добу ці показники були в межах фізіологічних величин.

Отже, на основі наших досліджень встановлено позитивну дію ліпосомального препарату “Бутаселмевіт" на організм щурів, які були інтоксиковані тетрахлорметаном, що проявляється нормалізацією гематологічних показників, функціонального стану та протеїнсинтезувальної функції печінки.

Розвиток оксидаційного стресу у щурів, викликаний внутрішньом'язовою ін'єкцією тетрахлорметану, супроводжувався пригніченням активності глутатіонової системи антиоксидантного захисту. Так, у щурів дослідної групи Д виявили зниженням активності глутатіонпероксидази, ензиму, який забезпечує захист 
мембран клітин від руйнівної дії пероксидних радикалів. Даний ензим каталізує розпад перекису водню і окиснює глутатіон. Встановлено, що на 2-у добу досліду активність глутатіопероксидази у крові дослідної групи щурів була найнижчою, де відносно контрольної групи вона знизилася на $61 \%$. У подальшому активність досліджуваного ензиму у крові щурів за умов розвитку оксидаційного стресу, дещо зростала, однак порівнюючи 3 контрольною групою щурів вона була нижчою на 53\%. На 10-ту і 14-ту доби досліду активність глутатіонпероксидази у крові щурів дослідної групи коливалась у межах величин $0,135 \pm 0,014-$ $0,147 \pm 0,017$ нмоль $\mathrm{GSH} /$ хв $\times$ мг білка.

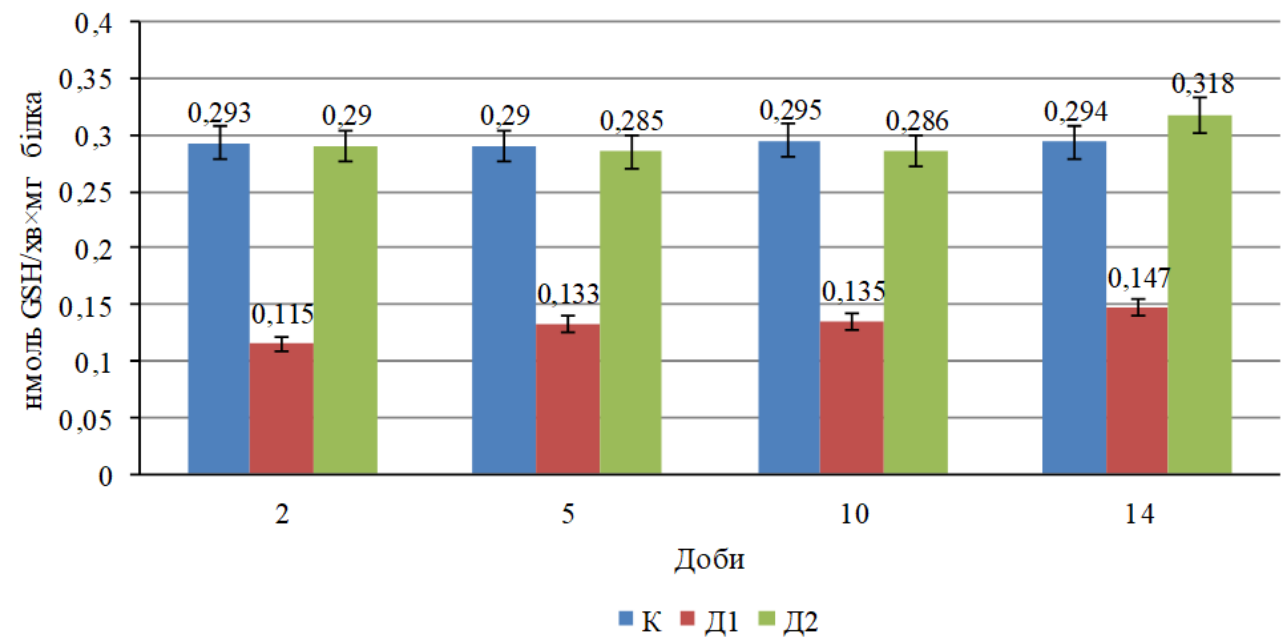

Рис. 1. Активність глутатіонпероксидази у сироватці крові щурів за умов оксидаційного стресу та за дії ліпосомального препарату “Бутаселмевіт”

Глутатіон відновлений є основним сірковмісним антиоксидантом в організмі тварин. Він захищає сульфгідрильні групи глобіну, мембрани еритроцитів, двовалентне залізо від дії окиснювачів. Він є центральним компонентом системи антиоксидантного захисту майже всіх клітин і органів. Його антиоксидантна дія пов'язана 3 перенесенням сульфгідрильних груп (Gutyj et al., 2017). За розвитку оксидаційного стресу рівень відновленого глутатіону у крові дослідної групи щурів на другу добу досліду знизився на 50\% відносно контрольної групи. Найнижчим рівень відновленого глутатіону був у крові дослідної групи щурів на п'яту добу досліду, де відповідно коливався у межах величин 0,255 $\pm 0,014$ мкмоль/мл. На 10-ту і 14-ту доби досліду рівень досліджуваного показника порівняно $з$ контрольною групою був нижчим на 45 і 47\%.

Незначне підвищення активності глутатіонпероксидази та рівня відновленого глутатіону в останні доби досліду, можливо, зумовлене тим, що відбувається посилене утворення радикальних метаболітів i збільшується вміст продуктів перекисного окиснення ліпідів, внаслідок токсичної дії тетрахлорметану. За цих умов, включається захисна реакція організму тварин на дану патологію і активується система антиоксидантного захисту організму. У цілому одержані нами результати досліджень вказують про те, що розвиток оксидаційного стресу призводить до порушення рівноваги у комплексі “Система антиоксидантного захисту - Перекисне окиснення ліпідів”.

Для боротьби 3 проявами токсичного ураження печінки в останні роки все частіше застосовують пре- парати-антиоксиданти для корекції системи антиоксидантного захисту та знешкодженню продуктів вільнорадикального окиснення (Gutyj et al., 2017). Пошук діючих речовин 3 антиоксидантними властивостями досить перспективний напрям досліджень, хоча i вимагає врахування проблеми сумісності природних та синтетичних антиоксидантів. Визначальними факторами антиоксидантної дії препарату є загальна чисельність речовин-антиоксидантів у його складі, якісний антиоксидантний спектр (наявність вітамінів, вітаміноподібних речовин, мікроелементів-металів), а також - загальний кількісний вміст речовин 3 антиоксидантними властивостями

За дії ліпосомального препарату “Бутаселмевіт” у крові щурів дослідної групи Д2 за розвитку оксидаційного стресу на другу добу досліду встановлено вірогідне підвищення активності глутатіонпероксидази до 0,290 $\pm 0,015$ нмоль GSH/хв $\times$ мг білка та рівня відновленого глутатіону до $0,615 \pm 0,033$ мкмоль/мл, де відносно тварин першої дослідної групи вони зросли на 60 і 132\%. На п'яту добу досліду активність глутатінпероксидази у сироватці крові дослідної групи Д дещо знизилася відносно попередньої доби, однак порівняно з хворими щурами, яких не лікували, була вищою на $114 \%$.

На десяту добу досліду рівень відновленого глутатіону у крові щурів дослідної групи, яким вводили ліпосомальний препарат, коливався у межах величин $0,675 \pm 0,023$ мкмоль/мл, що у 2,4 рази був вищим за показники тварин дослідної групи Д ${ }_{1}$ 


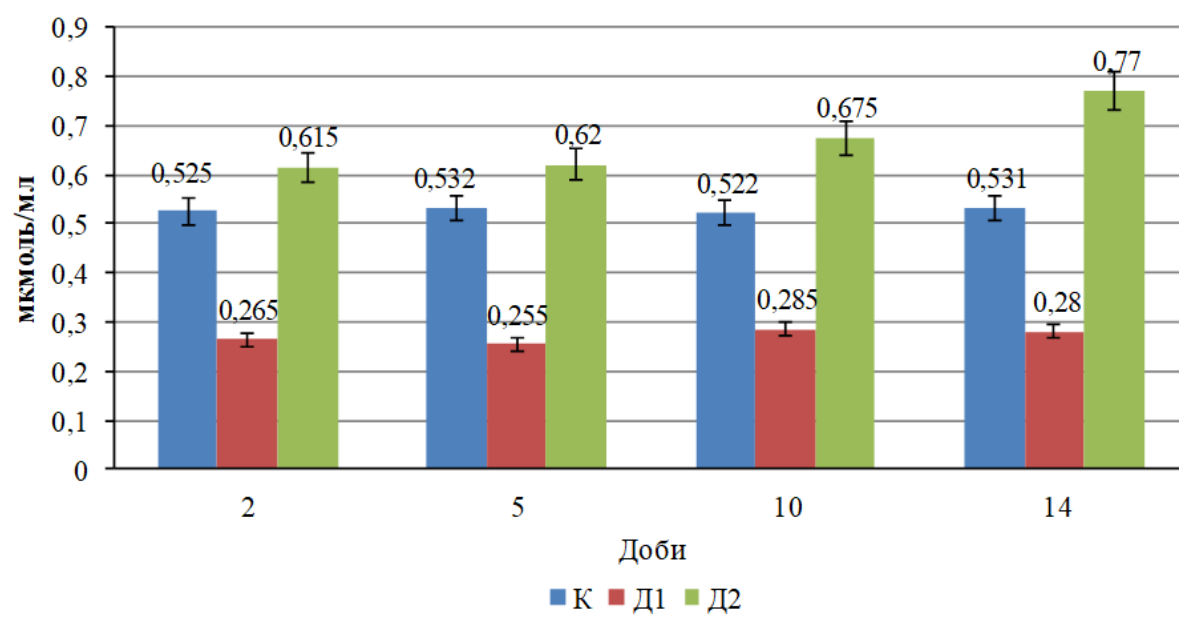

Рис. 2. Рівень відновленого глутатіону у крові щурів за умов оксидаційного стресу та за дії ліпосомального препарату "Бутаселмевіт"

У вказаний період досліду активність глутатіонпероксидази у сироватці крові щурів дослідної групи Д 2 коливалася у межах величин 0,286 $\pm 0,022$ нмоль

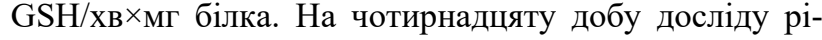
вень відновленого глутатіону та активність глутатіонпероксидази у крові щурів, яким застосовували ліпосомальний препарат, були найвищими.

Отже, ліпосомальний препарат "Бутаселмевіт" після застосування щурам за розвитку оксидаційного стресу пригнічував процеси перекисного окиснення ліпідів та активізував систему антиоксидантного захисту, на що вказує високий рівень відновленого глутатіону та активність глутатіонпероксидази. Це, можливо пов'язано з тим, що до складу препарату входять такі два сильні антиоксиданти, як вітамін Е та селен, які у свою чергу посилюють дію один одного і таким чином пригнічують радикалоутворення та процеси перекисного окиснення ліпідів. Також слід зауважити про антиоксидантні властивості розторопші плямистої, яка згідно даних літератури також володіє антиоксидантними властивостями. До іiі складу входять вітаміни групи В, А, Е, К, попередники вітаміну Д, каротиноїди, макроелементи - калій, кальцій, магній, Ферум та мікроелементи - Купрум, Цинк, Марган, Йод. Сумарна дія вказаних біологічно важливих елементів проявляє високу гепатопротекторну та антиоксидантну дії.

Отже, ліпосомальний препарат "Бутаселмевіт” попереджує розвиток оксидаційного стресу за токсичної дії тетрахлорметану.

\section{Висновки}

Розвиток оксидаційного стресу у щурів, викликаний внутрішньом'язовою ін'єкцією тетрахлорметану, супроводжувався пригніченням протеїнсинтезувальної функції печінки, на що вказує низький рівень загального протеїну та зниження альбуміноглобулінового коефіцієнту. Низький рівень альбумінів та високий рівень глобулінів у крові хворих щурів вказує на альбуміно-глобулінову диспропорцію. Досить високими були показники функціонального стану печінки, а саме: рівень креатиніну зріс на 46\%, сечовини на 74\% та білірубіну загального на 34\%. Після застосування ліпосомального препарату "Бутаселмевіт" щурам, за умов оксидаційного стресу протягом досліджень, у крові настає нормалізація біохімічних показників

Встановлено, що моделювання стресової реакції у щурів дослідної групи призводить до вірогідного зниження рівня відновленого глутатіону та активності глутатіонпероксидази на другу та п'яту доби експерименту. Після застосування ліпосомального препарату "Бутаселмевіт" щурам, за умов оксидаційного стресу протягом досліджень, у крові настає активація глутатіонової ланки антиоксидантної системи, на що вказує підвищення рівня відновленого глутатіону та активності глутатіонпероксидази у крові даних тварин. На 14 добу досліду рівень відновленого глутатіону та активність глутатіонпероксидази у крові дослідної групи Д2 були найвищими. Результати проведених досліджень вказують про антиоксидантні властивості нового ліпосомального препарату "Бутаселмевіт".

Перспективою подальших досліджень є вивчення впливу ліпосомального препарату "Бутаселмевіт" на захисні системи продуктивних тварин за розвитку оксидаційного стресу.

\section{References}

Li, D., Cai, H., Hou, M., Fu, D., Luo, Q., Yuan, X., Lv, M., Zhang, X., Cong, X., \& Lv, Z. (2012) Effects of indoleamine 2,3-dioxygenases in carbon tetrachlorideinduced hepatitis model of rats. Cell Biochem Funct, 30(4), 309-314. doi: 10.1002/cbf.2803.

Gutiy, B.V. (2012). Vplyv hlorydu kadmiyu na intensivnist protsesiv perekisnogo okysnennya lipidiv ta stan sistemy antyoksydantnogo zahystu organizmu shchuriv. Visnyk Sumskogo natsionalnogo agrarnogo universitetu, 7(31), 31-34 (in Ukrainian).

Gutyj, B.V. (2016). Osobennosti funkcionirovanija sistemy antioksidantnoj zashhity organizma krys pri kadmievom toksikoze. Nauchno-prakticheskij zhurnal. Uchenye Zapiski, 52(2), 24-28 (in Russian).

Calabrese, E., Leonard, D., \& Zhao, X. (1996). Role of tissue repair in carbon tetrachloride hepatotoxicity in male and 
female Sprague-Dawley and Wistar rats. Int. J. Toxicol., 15, 62-69. doi: 10.3109/10915819609008707.

Cherkashina, D.V., \& Petrenko, A.Y. (2006). Hepatoprotective effect of fetal tissue cytosol and its thermostable fraction in rats with carbon tetrachloride-induced hepatitis. B. Exp. Biol. Med., 141(4), 544-547. doi: 10.1007/s10517-006-0216-y.

Abragamovich, O.O., Grabovska, O.I., \& Terletska, O.I. (2000). Protsesy lipidnoyi peroksidatsiyi pry hronichnyh urazhennyah pechinky. Medichna himiya, 2(1), 5-8 (in Ukrainian).

Hariv, M.I., \& Gutyj, B.V. (2016). Influence of the liposomal preparation Butaintervite on protein synthesis function in the livers of rats under the influence of carbon tetrachloride poisoning. Visnyk of Dnipropetrovsk University. Biology, medicine, 7(2), 123-126. doi: 10.15421/021622.

Sato, S., Dai, W., Liu, X.-L., Asano, G. (1999). The protective effect of hepatocyte growth-promoting factor (pHGF) against carbon tetrachloride-induced acute liver injury in rats: An ultrastructural study. Med. Electron $\quad$ Microsc., 32(3), 184-192. doi: $10.1007 / \mathrm{s} 007950050026$.

Yatsenko, O.Iu., \& Maloshtan, O.L. (2004). Vplyv rybiflanu na funktsionalnyi stan pechinky shuriv pry khronichnomu urazhenni tetrakhlormetanom. Visnyk farmatsii, 1(37), 67-70 (in Ukrainian).

Batakov, E.A. (2001) Effect of Silibum marianum oil and legalon on lipid peroxidation and liver antioxidant systems rats intoxicates with carbon tetrachloride. Eksp. Klin. Farmakol., 64(4), 53-55. https://www.ncbi.nlm.nih.gov/pubmed/11589112.

Gutyj, B.V., Murs'ka, S.D., Gufrij, D.F., Hariv, I.I., Levkivs'ka, N.D., Nazaruk, N.V., Gajdjuk, M.B., Pryjma, O.B., Bilyk, O.Ja., \& Guta, Z.A. (2016). Influence of cadmium loading on the state of the antioxidant system in the organism of bulls. Visnyk of Dnipropetrovsk University. Biology, ecology, 24(1), 96-102. doi: 10.15421/011611.

Gutyj, B., Lavryshyn, Y., Binkevych, V., Binkevych, O., Paladischuk, O., Strons'kyj, J., \& Hariv, I. (2016). Influence of «Metisevit» on the activity of enzyme and nonenzyme link of antioxidant protection under the bull's body cadmium loading. Scientific Messenger LNUVMBT named after S.Z. Gzhytskyj, 18, 2(66), 52-58. doi: 10.15421/nvlvet6612.

Gutyj, B., Paska, M., Levkivska, N., Pelenyo, R., Nazaruk, N., \& Guta, Z. (2016). Study of acute and chronic toxicity of 'injectable mevesel' investigational drug. Biological Bulletin of Bogdan Chmelnitskiy Melitopol State Pedagogical University, 6(2), 174180. doi: 10.15421/201649.

Gutyj, B.V., Hufriy, D.F., Hunchak, V.M., Khariv, I.I., Levkivska, N.D., \& Huberuk, V.O. (2016). The influence of metisevit and metifen on the intensity of lipid per oxidation in the blood of bulls on nitrate load. Scientific Messenger LNUVMBT named after S.Z. Gzhytskyj, 18, 3(70), 67-70 doi: 10.15421/nvlvet7015.

Khariv, M., Gutyj, B., Butsyak, V., \& Khariv, I. (2016). Hematological indices of rat organisms under conditions of oxidative stress and liposomal preparation action. Biological Bulletin of Bogdan Chmelnitskiy Me- litopol State Pedagogical University, 6(1), 276-289. doi: $10.15421 / 201615$.

Martyshuk, T.V., Gutyj, B.V., \& Vishchur, O.I. (2016). Level of lipid peroxidation products in the blood of rats under the influence of oxidative stress and under the action of liposomal preparation of " $\mathrm{Bu}$ taselmevit", Biological Bulletin of Bogdan Chmelnitskiy Melitopol State Pedagogical University, 6 (2), 22-27. doi: 10.15421/201631.

Huberuk, V., Gutyj, B., Gufriy, D., Binkevych, V., Hariv, I., Binkevych, O., \& Salata, R. (2017). Impact of antioxidants on enzym activities of glutatione system of bulls bodies antioxidant defense under acute nitrate and nitrite toxicity. Scientific Messenger LNUVMBT named after S.Z. Gzhytskyj, 19(77), 220-224. https://nvlvet.com.ua/index.php/journal/article/view/12 12.

Lavryshyn, Y.Y., Varkholyak, I.S., Martyschuk, T.V., Guta, Z.A., Ivankiv, L.B., Paladischuk, O.R., Murska, S.D., Gutyj, B.V., \& Gufriy, D.F. (2016). The biological significance of the antioxidant defense system of animals body. Scientific Messenger LNUVMBT named after S.Z. Gzhytskyj, 18, 2(66), 100-111. doi: 10.15421/nvlvet6622.

Khariv, M., Gutyj, B., Ohorodnyk, N., Vishchur, O., Khariv, I., Solovodzinska, I., Mudrak, D., Grymak, C., \& Bodnar, P. (2017). Activity of the T- and B-system of the cell immunity of animals under conditions of oxidation stress and effects of the liposomal drug. Ukrainian Journal of Ecology, 7(4), 536-541. doi: 10.15421/2017 157 .

Lee, J.Y., Lee, J.H., \& Kim, H.J. (2004). The preventive inhibition of chondroitin sulfate against the CCI4induced oxidative stress of subcellular level. Arch. Pharm. Res., 27(3), 340-345. https://www.ncbi.nlm.nih.gov/pubmed/15089041.

Skry`pny`k, I.M. (2007). Gepatoprotetorni zasoby` v suchasnij gepatologiyi. Consilium Medicumllkraina, 1(5), 11-15 (in Ukrainian).

Saba, A.B., Oyagbemi, A.A., \& Azeez, O.I. (2010). Amelioration of carbon tetrachloride-induced hepatotoxicity and haemotoxicity by aqueous leaf extract of Cnidoscolus aconitifolius in rats. Nig. J. Physiol. Sci., 25(2), 139-147. https://www.ncbi.nlm.nih.gov/ pubmed/22314953.

Antonyak, G.L., Babich, N.O., \& Sologub, L.I. (2000). Utvorennya aktivnih form kisnyu ta sistema antioksidantnogo zahistu $\mathrm{v}$ organizmi tvarin. Biologiya tvaryn, 2(2), 34-43 (in Ukrainian).

Belenichev, I.F. Levitskiy, E.L., \& Kovalenko, S.I. (2002) Antioksidantna sistema zahistu organizmu (oglyad). Sovremennye problemy toksikologii, 3, 29-31 (in Russian).

Gutyj, B., Khariv, I., Binkevych, V., Binkevych, O., Levkivska, N., Levkivskyj, D., \& Vavrysevich, Y. (2017). Research on acute and chronic toxity of the experimental drug Amprolinsyl. Regulatory Mechanisms in Biosystems, 8(1), 41-45. doi: 10.15421/021708.

Gutyj, B., Grymak, Y., Drach, M., Bilyk, O., Matsjuk, O., Magrelo, N., Zmiya, M., \& Katsaraba, O. (2017). The impact of endogenous intoxication on biochemical indicators of blood of pregnant cows. Regulatory Mech- 
anisms in Biosystems, 8(3), 438-443. of liposomal preparation. Regulatory Mechanisms in doi: $10.15421 / 021768$.

Biosystems, 8(2), 304-309. doi: 10.15421/021748.

Gutyj, B., Martyshchuk, T., Bushueva, I., Semeniv, B., Vlizlo, V.V., Fedoruk, R.S., \& Ratych, I.B. (2012). Parchenko, V., Kaplaushenko, A., Magrelo, N., Hirkovyy, A., Musiy, L., \& Murska, S. (2017). Morphological and biochemical indicators of blood of rats Laboratory methods of investigation in biology, stockbreeding and veterinary. A reference book. Ed. by VV poisoned by carbon tetrachloride and subject to action 